\title{
Chromosome complement and meiosis in three species of the Neotropical bug genus Antiteuchus (Heteroptera, Pentatomidae, Discocephalinae)
}

\author{
Cecilia Lanzone and Maria José de Souza \\ Universidade Federal de Pernambuco, Departamento de Genética, Recife, Pernambuco, Brazil.
}

\begin{abstract}
Orcein staining of spermatocytes was used to study the meiotic behavior of holocentric chromosomes in three member of the genus Antiteuchus (commonly known as stink bugs). We describe and illustrate the karyotype of Antiteuchus mixtus, $A$. sepulcralis and $A$. macraspis which were cytogenetically characterized as having a diploid number of $2 n=14$ and an $X Y$ sex chromosome system showing pre-reductional meiosis for autosomes and post-reductional meiosis for sex chromosomes. These species were also shown to have a long diffuse stage during meiotic prophase I and aberrant harlequin-type meiocytes. The chiasma frequency was also analyzed for two of the three species studied.
\end{abstract}

Key words: spermatogenesis, holokinetic chromosomes, sex chromosomes, meiosis, diffuse stage.

Received: February 14, 2005; Accepted: June 8, 2005.

\section{Introduction}

Heteroptera represents a group of insects that possesses holocentric chromosomes showing diffuse centromeres or holokinetic activity. In such organisms, during meiosis, kinetic activity is shifted to the telomeric regions, transforming both autosomes and sex chromosomes into telokinetic chromosomes (González-Garcia et al., 1996; Pérez et al., 1997, 2000).

Another characteristic of Heteroptera is the presence of inverted meiosis restricted to the male sex chromosomes. In the case of these chromosomes, the first meiotic division is equational, with segregation of the sister chromatids. The second division is equational for autosomes and reductional for sex chromosomes. This pattern of sex chromosome segregation is widely distributed in this suborder, with few exceptions (Ueshima, 1979; Nokkala and Nokkala, 1984; Camacho et al., 1985). In species with an XY sex-system, the meiotic metaphases are generally radial and the sex chromosomes are found in the center of the meiotic plate. During the first division, the sex chromosomes are univalent, while during telophase I or metaphase II the $\mathrm{X}$ and $\mathrm{Y}$ chromosomes form a pseudobivalent that segregates in a post-reductional manner in male second meiotic division. In addition, a particular type of testicular follicle called a harlequin lobe, which produces abnormal sperma-

Send correspondence to Maria José de Souza. Universidade Federal de Pernambuco, Departamento de Genética, Av. Prof. Moraes Rego, Cidade Universitária, 50732-970 Recife, Pernambuco, Brazil. E-mail: mjslopes@uol.com.br. tozoa, has been described in the family Pentatomidae, mainly in the subfamily Discocephalinae (Ueshima, 1979; Rebagliati et al., 2001).

Heteropteran insects are also characterized by the presence of a special stage of prophase I, called the diffuse stage, during which chromosome de-condensation occurs. After this stage, a new round of condensation occurs and the chromosomes reappear condensed in the late diplotene phase (Ueshima, 1979).

The family Pentatomidae (stink bugs) contains eight subfamilies with a worldwide distribution (Schuh and Slater, 1995). Representatives of the subfamily Discocephalinae have a diploid number of $2 \mathrm{n}=14$ and a XX:XY sex chromosome mechanism (Ueshima, 1979). In this paper we present the first report on the karyotype of three Antiteuchus species belonging to the Discocephalinae and also discuss chromosome behavior in these species during spermatogenesis.

\section{Materials and Methods}

We studied male adult Antiteuchus mixtus (Fabricius 1787), Antiteuchus sepulcralis (Fabricius 1803) (= Mecistorhinus sepulcralis) and Antiteuchus macraspis (Perty 1834) (= Neodine macraspis) obtained from different populations in northeastern Brazil (Table 1). Most $A$. mixtus and $A$. sepulcralis specimens were collected from Clitoria racemosa (Leguminosae) while A. macraspis specimens were obtained from Terminalia catappa (Combretaceae). Testes were extracted and fixed in 3:1 eth- 
anol:acetic acid and slides prepared using the classical squashing technique and stained with $2 \%$ lactoacetic orcein for conventional analysis. Due to the low number of $A$. macraspis specimens only $A$. mixtus and $A$. sepulcralis specimens were submitted to quantitative analysis. Photo-

Table 1 - Localities and number of males analyzed for each of the three Antiteuchus species and geographical coordinates.

\begin{tabular}{|c|c|c|c|}
\hline Species & Localities & $\begin{array}{l}\text { N. of } \\
\text { males }\end{array}$ & Coordinates \\
\hline \multirow[t]{4}{*}{ A. mixtus } & Recife (PE) & 30 & 8०3’14”S:3452’52”W \\
\hline & Pilar (AL) & 2 & $9^{\circ} 35^{\prime} 50^{\prime \prime} \mathrm{S}: 35^{\circ} 57^{\prime} 24^{\prime \prime} \mathrm{W}$ \\
\hline & Rio de Contas (BA) & 3 & $13^{\circ} 34^{\prime} 44^{\prime \prime} \mathrm{S}: 41^{\circ} 48^{\prime} 41^{\prime \prime} \mathrm{W}$ \\
\hline & Sobradinho (BA) & 7 & 9॰27’19”S:4049’24”W \\
\hline \multirow[t]{3}{*}{ A. sepulcralis } & Recife (PE) & 15 & 8’3’14”S:3452’52”W \\
\hline & Pilar (AL) & 2 & $9^{\circ} 35^{\prime} 50^{\prime \prime} \mathrm{S}: 35^{\circ} 57^{\prime} 24^{\prime \prime} \mathrm{W}$ \\
\hline & Rio de Contas (BA) & 4 & $13^{\circ} 34^{\prime} 44^{\prime \prime S}: 41^{\circ} 48^{\prime} 41^{\prime \prime} \mathrm{W}$ \\
\hline A. macraspis & Pt. de Galinhas (PE) & 6 & $8^{\circ} 23^{\prime} 56^{\prime \prime} \mathrm{S}: 35^{\circ} 3^{\prime} 50^{\prime \prime} \mathrm{W}$ \\
\hline
\end{tabular}

graphs were taken using a Leitz Orthoplan microscope and Kodak Imagelink 25 film. Copies were obtained using Kodak Kodabrome F3 paper.

\section{Results}

The diploid chromosome complement of $A$. mixtus, A. sepulcralis and $A$. macraspis males was determined to be $2 \mathrm{n}=14, \mathrm{XY}$ with the autosomal chromosomes decreasing in size within each species. The $\mathrm{X}$ chromosome was similar in size to the penultimate autosome pair and the Y chromosome was the smallest one in the complement and presented a small variation in size in the three species analyzed (Figures 1 and 2).

It was possible to subdivide the meiotic prophase of these species into all the traditional stages plus an additional diffuse stage between pachytene and diplotene (Figure 1b), pachytene being relatively frequent in these species (Figure 1a). In some cells a bouquet-like polarization involving clustering of the telomeres in a restricted region of

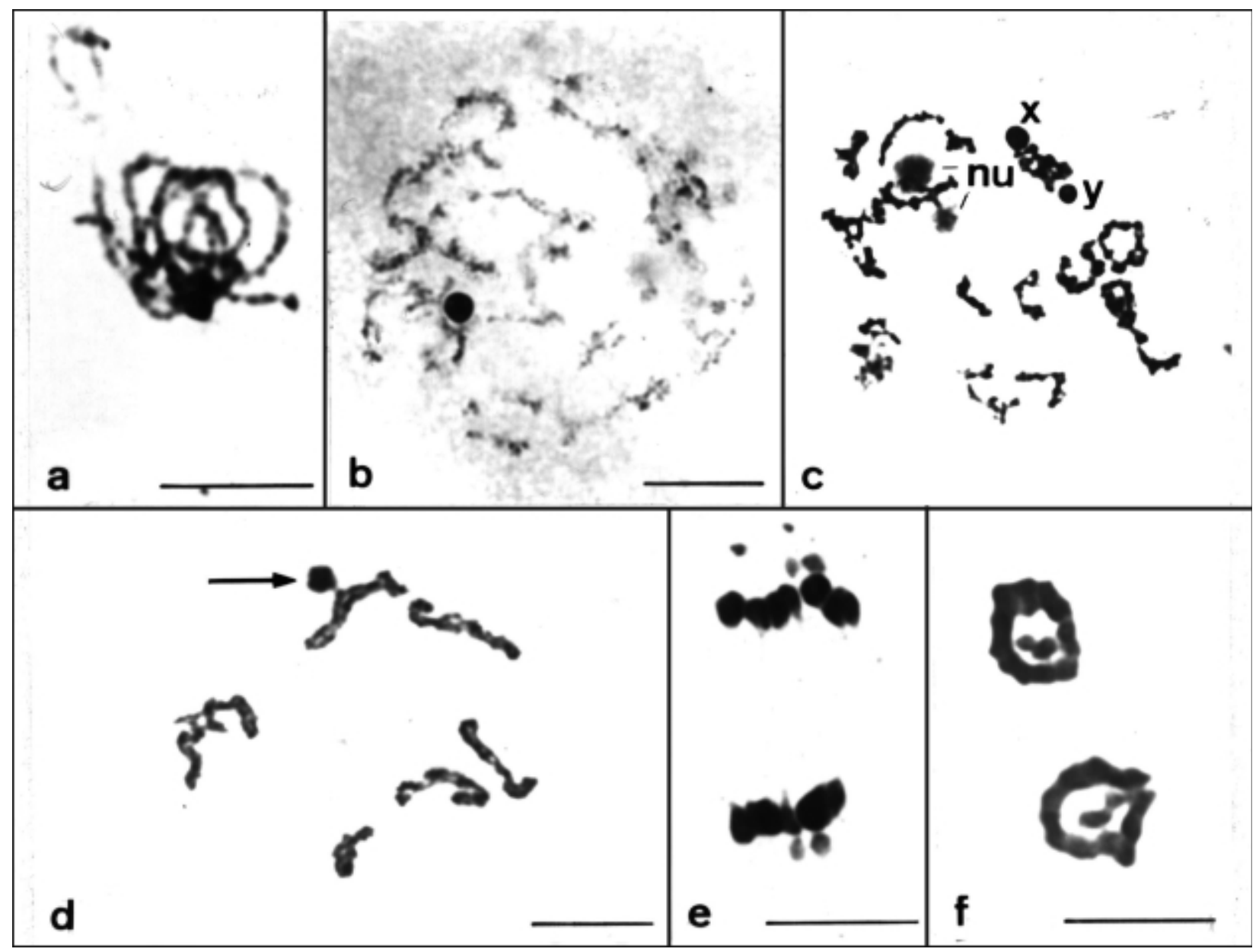

Figure 1 - Male meiotic chromosomes of three Antiteuchus species. a-c: A. sepulcralis (a) pachytene, note the sex chromosomes at the base of the bouquet; (b) diffuse stage of maximum de-condensation showing the condensed and paired sex chromosomes; (c) late diffuse stage showing the nucleolus (nu) and the unpaired sex chromosomes; (d) diplotene in A. mixtus, paired sex chromosomes associated (arrow) with an autosomal bivalent at the chiasmatic end; (e) anaphase I in A. sepulcralis, showing the sex chromosomes migrating in front of the autosomes; and (f) radial telophase in $A$. mixtus with the sex chromosomes in the center. Bar $=10 \mu \mathrm{m}$. 
the nucleus was observed, the sex chromosomes generally being paired at the base of this structure (Figure 1a). The diffuse stage appeared to be the longest meiotic stage as demonstrated by its high frequency in the preparations, and was associated with remarkable cell size. During the diffuse stage the autosomes underwent de-condensation while the sex chromosomes remained condensed and heteropycnotic (Figure 1b). The autosomes entered in the diffuse stage as synaptic bivalents after pachytene and left it as chiasmatic bivalents during the late diplotene as a consequence of a new round of condensation. Intensely stained preparations showed a prominent nucleolus, especially during the pachytene and the diffuse stages (Figure 1c).

The $\mathrm{X}$ and $\mathrm{Y}$ chromosomes showed a different condensation cycle from that of the autosomes in the meiotic prophase I, being heteropycnotic until diplotene when their staining pattern changed to that observed for autosomes at the end of the diplotene or diakinesis stages (Figure 1d). Furthermore, the Y chromosome was generally negatively heteropycnotic both at metaphase I and metaphase II. During the prophase stages, the sex chromosomes differed morphologically from the autosomes as well and generally showed a round shape, probably due to association involving their telomeres.

During all stages preceding diakinesis the $\mathrm{X}$ and $\mathrm{Y}$ chromosomes were associated with each other but these configurations rarely persisted until diakinesis, during which the sex chromosomes were often observed as rodshaped univalents with no telomeric associations. Moreover, at the end of the diffuse stage and diplotene, when the bivalents were clearly distinguishable, the $\mathrm{X}$ and $\mathrm{Y}$ chromosomes tended to associate with the telomeric regions of autosomal chromosomes (Figure 1c) and were found as pseudobivalents associated with an autosomal bivalent or, alternatively, both chromosomes were univalent and independently associated with one or two autosomal bivalents. The frequency of sex chromosome pairing and their autosomal association showed that in A. sepulcralis these

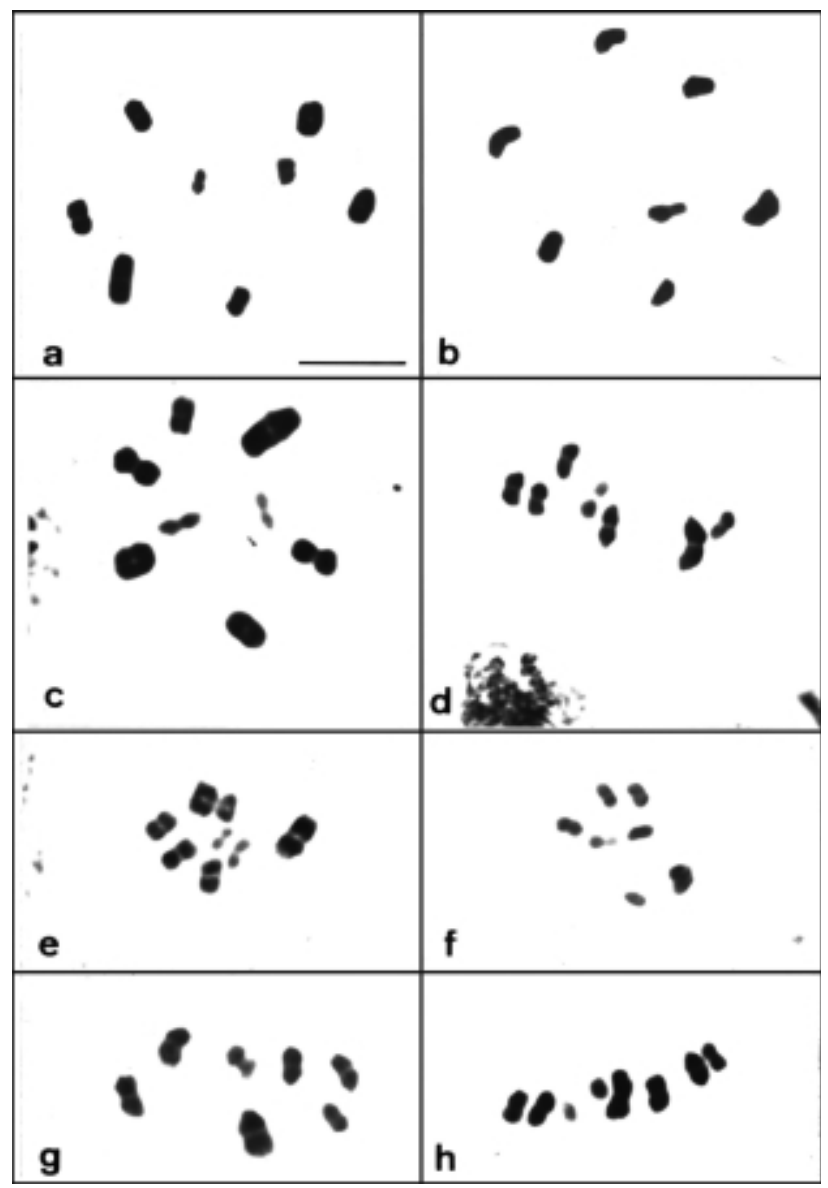

Figure 2 - Meiotic metaphases of the three Antiteuchus species: (a,b,g) A. mixtus, (c,d,h) A. sepulcralis, (e, f) A. macraspis. (a,c,e) radial metaphases I and (b,d,f,g,h) metaphases II with the sex chromosomes in the center of the ring formed by the autosomes. (g) Metaphase II showing the side-by-side pairing of the XY-pseudobivalent, and (h) the X and Y chromosomes appear as univalents. $\mathrm{Bar}=10 \mu \mathrm{m}$.

chromosomes are more often univalent and associated with an autosomal bivalent than in $A$. mixtus (Table 2).

In diplotene, the autosomal bivalents generally presented a chiasma in the terminal region. Analysis of the fre-

Table 2 - Absolute and relative (\%) frequency of sex chromosome association and their association with autosomal bivalents in Antiteuchus mixtus and Antiteuchus sepulcralis ${ }^{1}$.

\begin{tabular}{|c|c|c|c|c|c|c|c|c|c|}
\hline \multirow[t]{2}{*}{ Species } & \multirow[t]{2}{*}{$\begin{array}{l}\text { N. of cells } \\
\text { analyzed }(\mathrm{N})\end{array}$} & \multicolumn{3}{|c|}{$\begin{array}{c}\text { Autosome association of paired XY } \\
\text { sex chromosomes }(\%)^{3}\end{array}$} & \multicolumn{5}{|c|}{$\begin{array}{c}\text { Autosome association of unpaired } \mathrm{X} \text { and } \mathrm{Y} \\
\text { sex chromosomes }(\%)^{4}\end{array}$} \\
\hline & & Unassociated & Associated & Total $^{2}$ & Unassociated & $\mathrm{X}$ associated & $\mathrm{Y}$ associated & $\begin{array}{l}\text { Both } \mathrm{X} \text { and } \\
\mathrm{Y} \text { associated }\end{array}$ & Total $^{2}$ \\
\hline $\begin{array}{l}\text { Antiteuchus } \\
\text { mixtus }\end{array}$ & 178 & $\begin{array}{c}65 \\
(36.52)\end{array}$ & $\begin{array}{c}19 \\
(10.67)\end{array}$ & $\begin{array}{c}84 \\
(47.19)\end{array}$ & $\begin{array}{c}47 \\
(26.41)\end{array}$ & $\begin{array}{c}16 \\
(8.99)\end{array}$ & $\begin{array}{c}23 \\
(12.92)\end{array}$ & $\begin{array}{c}8 \\
(4.49)\end{array}$ & $\begin{array}{c}94 \\
(52.81)\end{array}$ \\
\hline $\begin{array}{l}\text { Antiteuchus } \\
\text { sepulcralis }\end{array}$ & 142 & $\begin{array}{c}25 \\
(17.61)\end{array}$ & $\begin{array}{c}22 \\
(15.49)\end{array}$ & $\begin{array}{c}47 \\
(33.10)\end{array}$ & $\begin{array}{c}22 \\
(15.49)\end{array}$ & $\begin{array}{c}10 \\
(7.04)\end{array}$ & $\begin{array}{c}35 \\
(24.65)\end{array}$ & $\begin{array}{c}28 \\
(19.72)\end{array}$ & $\begin{array}{c}95 \\
(66.90)\end{array}$ \\
\hline
\end{tabular}

${ }^{1}$ Comparison between the two species considering all classification categories: Pearson $\chi_{(5)}^{2}=38.4706, \mathrm{p}<0.000$.

${ }^{2}$ Frequency comparison of the sex chromosome association between species: Pearson $\chi_{(1)}^{2}=6.4878$, Fisher exact test: $p=0.012$.

${ }^{3}$ Differences between species in the association between the XY chromosomes and autosomes in the case of pairing: Pearson $\chi^{2}{ }_{(1)}=8.2011$, Fisher exact test: $\mathrm{p}=0.006$.

${ }^{4}$ Differences between species in respect of the association between the XY pair and autosomes in the case of unpairing: Pearson $\chi^{2}(3)=24.0318, \mathrm{p}<0.000$. 
quency and distribution of the chiasmata in A. mixtus (7 specimens) and $A$. sepulcralis (4 specimens) revealed a mean total number of chiasmata per cell of $6.11 \pm 0.33$ $(\mathrm{N}=123)$ for $A$. mixtus and $6.09 \pm 0.29(\mathrm{~N}=99)$ for $A$. sepulcralis. Chiasmata located in the subterminal regions were present at an intermediate frequency while interstitial chiasmata were very rare in both $A$. mixtus and $A$. sepulcralis (Table 3).

Metaphase plates were radial during both the first and second meiotic division in the three species analyzed. At metaphase I, univalent sex chromosomes were observed in the center of the ring formed by the autosomes (Figure $2 \mathrm{a}, \mathrm{c}$, e). At metaphase II, the X and Y chromosomes were associated, forming a pseudobivalent in the center of the spindle (Figure 2b, d, f). During this latter phase, telomere pairing of the $\mathrm{X}$ and $\mathrm{Y}$ chromosomes was observed in $87.93 \%$ of $A$. mixtus cells $(\mathrm{N}=315)$ and $87.18 \%$ of $A$. sepulcralis cells $(\mathrm{N}$ $=117$ ). Other types of pairing were also detected at a low frequency (Figure $2 \mathrm{~g}$ ). The pseudobivalent was found to be unpaired at metaphase II in $0.32 \%$ of $A$. mixtus cells and in $1.71 \%$ of $A$. sepulcralis cells (Figure $2 \mathrm{~h}$ ).

At anaphase $\mathrm{I}$, the $\mathrm{X}$ and $\mathrm{Y}$ chromosomes were either associated or slightly separated when they migrated, and connected to the same poles by thin chromatin bridges in $92.63 \%(\mathrm{~N}=190)$ of $A$. mixtus cells and in $82.5 \%(\mathrm{~N}=40)$ of $A$. sepulcralis cells. During this phase, the sex chromosomes were found in an advanced position compared to the autosomes in $61.05 \%$ of $\mathrm{A}$. mixtus cells and in $77.5 \%$ of $\mathrm{A}$. sepulcralis cells, indicating that their velocity of migration can be higher than that of the autosomes (Figure 1e). Telophases I were also radial and the intimately paired sex chromosomes could be observed in the center of the ring (Figure 1f).

We also observed that during diakinesis all three species showed the type of harlequin lobe follicle described for Discocephalinae species. At the beginning of diakinesis the chromosomes became associated with each other through thin chromatin bridges while at late diakinesis all autosomal bivalents were irregularly grouped, these groups sometimes containing the sex chromosomes and sometimes not. At metaphase I the autosomal bivalents formed a compact and round mass and the sex chromosomes occurred as univalents outside the autosomal group. Figure 3 highlights the harlequin type irregularities observed in the three species.

\section{Discussion}

Our study of Antiteuchus species showed a modal chromosome complement for the family Pentatomidae ( $2 \mathrm{n}=14, \mathrm{XY}$ in males), confirming high karyotypic conservation during the evolution of this group (Ueshima, 1979). However, in this family sex chromosomes behavior differs notably between species, with approximately $90 \%$ of Nezara viridula cells showing associated sex chromosomes during the diffuse stage and diplotene (Camacho et al., 1985) and similar behavior having been described for various other species of this family (Satapathy and Patnaik, 1988, 1991). In the Antiteuchus species analyzed by us the frequency of XY association was less than $50 \%$ and indicates a lower tendency towards association, such behavior having also been observed for some pentatomid species analyzed by Rebagliati et al. (2001). In A. sepulcralis we found that the association frequency of the Y chromosome with one of the telomeres of autosome 1 was $28.17 \%$ whereas association with the other autosomes was only $16.2 \%$, indicating the preferential association of this sex chromosome with some autosomes.

Sex chromosome association during the second meiotic division seems to be strongly influenced by the necessity for correct segregation. Stable orientation of the univalent chromosomes during meiosis has been shown to involve bipolar association of the sister kinetochores (Ault and Nicklas 1989; Rebollo et al., 1998) and we found radial metaphase plates associated with the sex chromosomes in the center in the three Antiteuchus species studied.

In heteropteran species with an XY sex chromosome system, pseudobivalent association generally occurs during telophase I or metaphase II (Ueshima, 1979; Camacho et al., 1985; Jacobs and Liebenberg, 2001). However, pseudobivalent formation might occur early in anaphase I or telophase I in both $A$. mixtus and $A$. sepulcralis. This precocious association of the $\mathrm{X}$ and $\mathrm{Y}$ chromosomes in anaphase $\mathrm{I}$ and their apparent faster migration represent a variation in the behavior of these chromosomes.

The presence of the diffuse stage is a frequent meiotic phenomenon among heteropterans, although its duration and the degree of chromosome de-condensation seems to vary between species, ranging from a high degree of decondensation (Solari, 1979; Nokkala and Nokkala, 1984; Camacho et al., 1985; Nokkala, 1986; Rebagliati et al., 1998) to partial de-condensation (Papeschi and Mola 1990;

Table 3 - Frequency and distribution of chiasmata in Antiteuchus mixtus and Antiteuchus sepulcralis. Comparison of the distribution of chiasmata between species: Pearson $\chi_{(2)}^{2}=11.0806, \mathrm{p}=0.004$.

\begin{tabular}{|c|c|c|c|c|c|}
\hline \multirow[b]{2}{*}{ Species } & \multirow[b]{2}{*}{$\begin{array}{c}\text { Number of cells } \\
\text { analyzed }\end{array}$} & \multirow[b]{2}{*}{$\begin{array}{c}\text { Total number of } \\
\text { chiasmata detected }\end{array}$} & \multicolumn{3}{|c|}{ Position of chiasmata $(\%)$} \\
\hline & & & Terminal & Subterminal & Interstitial \\
\hline A. mixtus & 123 & 750 & $509(67.87)$ & $198(26.4)$ & $43(5.73)$ \\
\hline A. sepulcralis & 99 & 603 & $452(74.96)$ & $113(18.74)$ & $38(6.30)$ \\
\hline
\end{tabular}




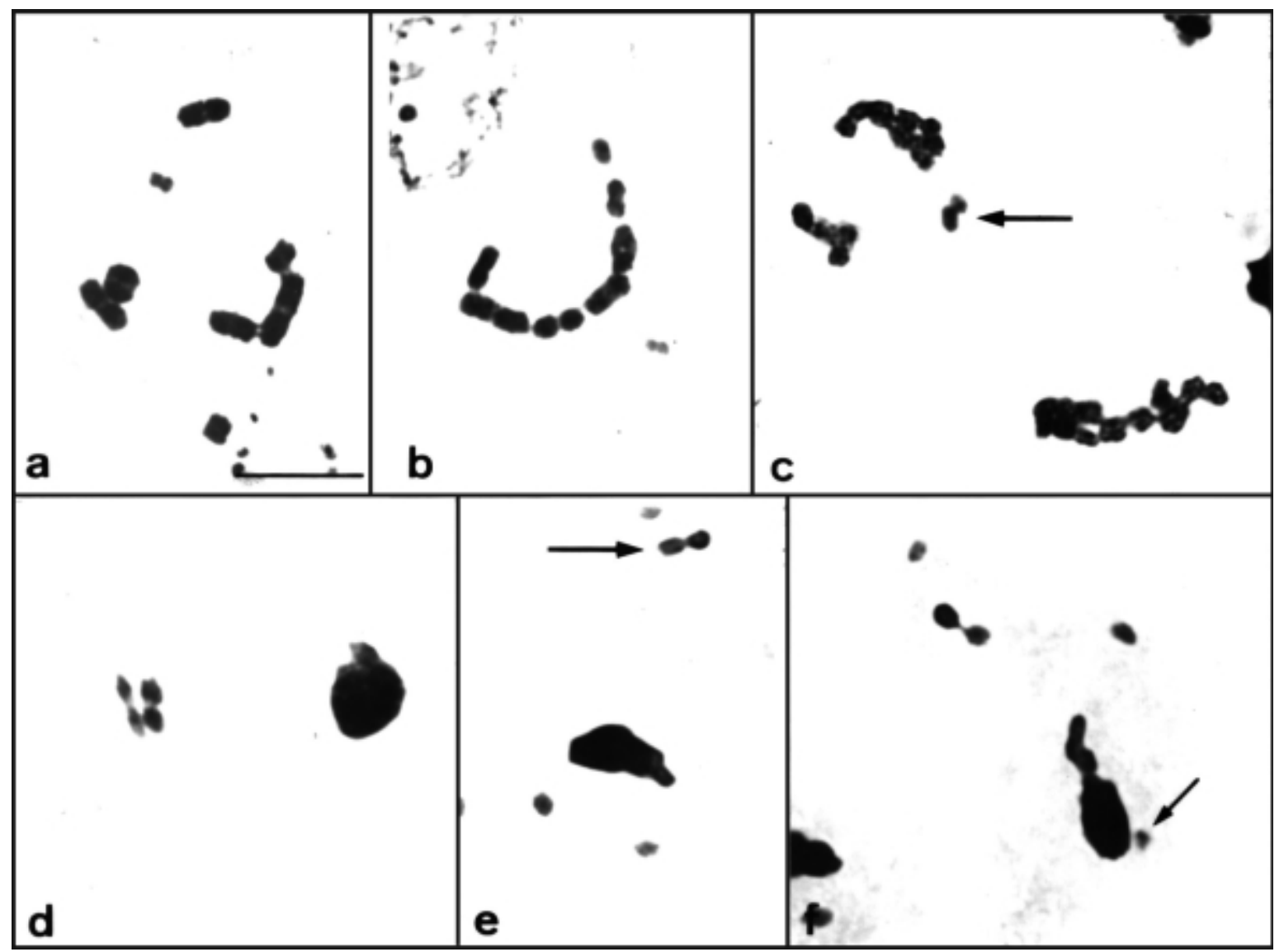

Figure 3 - Conventional staining shows sequential changes in the harlequin follicle abnormalities in the Antiteuchus species studied: (a) initial diakinesis, some autosomal bivalents become associated through thin chromatin bridges; (b) all autosomal bivalents are associated; (c) the autosomal bivalents are associated and the sex chromosomes (arrow) may or may not be part of the cluster; (d) metaphase I, showing the autosomal bivalents clustering without the sex chromosomes; (e) metaphase II, note the association between one autosome and the X chromosome (arrow), and (f) anaphase II, the X chromosome migrates to the same pole with one of the autosomes. In the sister spermatocyte, the Y chromosome (arrow) will remain with the non-reduced autosomal complement. Bar $=10 \mu \mathrm{m}$.

Jacobs and Liebenberg, 2001) up to cases of species whose chromosomes do not de-condense at all and which consequently do not have a diffuse stage (Jacobs and Liebenberg, 2001; Rebagliati et al., 2001). The three Antiteuchus species analyzed by us were characterized by a long diffuse stage and an ample degree of chromosome de-condensation during which the cells presented large nucleoli indicating strong transcriptional activity.

The meaning of the diffuse stage has not yet been completely established, although Stack and Anderson (2001) have suggested a model in which the chromosomes change from meiotic to mitotic organization during the diffuse stage which corresponds to a final G2 phase in which the de-condensed chromosomes are actively transcribed. Data obtained from most heteropterans agree with Stack and Anderson's model, which represents a mechanism of general chromosome organization which can be found in most organisms. It is possible that the differences in the duration and levels of de-condensation of the diffuse stage correspond to variations in the interval of disintegration be- tween the meiotic and mitotic chromosome structure among different organisms.

Heteroptera chiasmata distribution and frequency data show that they are located terminally and that there is a predominance of one chiasma per bivalent (Satapathy and Patnaik, 1988; González-Garcia et al., 1996; Grozeva and Nokkala, 1996; Bressa et al., 1999; Nokkala and Nokkala, 1999), although subterminal chiasmata have been observed in some species and two chiasmata have been noted in some bivalents (Camacho et al., 1985; Mola and Papeschi, 1993; Nokkala and Nokkala, 1997; Rebagliati et al., 2001).

We found that $A$. mixtus and $A$. sepulcralis bivalents often presented a single, usually terminal, chiasma and that the frequency of subterminal chiasmata was markedly higher than that of interstitial chiasmata, in contrast to what has been reported for most other bugs. However, it is possible that terminal and subterminal chiasmata have been classified as terminal by some authors. Analysis of chiasmata distribution in the major autosome pair of Myrmus miriformis (Corizidae) revealed that subterminal chiasmata were much more frequent than terminal and interstitial 
chiasmata, which means that the frequency and distribution of chiasmata is variable among heteropteran (Nokkala and Nokkala, 1997).

The aberrant harlequin-lobe meiocytes observed by us in Antiteuchus are known to be common in the Pentatomidae (Schrader, 1960). This abnormality includes heteropycnosis and clumping of autosomal bivalents at prophase, asynapsis and uneven segregation of chromosomes. This irregular chromosomal behavior might produce different types of aneuploid gametes (Ueshima, 1979).

The nucleolar cycle of the Antiteuchus species discussed in this paper resembled that of other heteropterans (Fossey and Liebenberg, 1995). Our observation of nucleolar activity during the diffuse stage might indicate prolonged activation during the cell cycle. Moreover, the presence of a nucleolus until diakinesis and a reactivation cycle during telophase I had been observed in Carlisis wahlbergi (Coreidae) which shows a meiotic cycle also characterized by a diffuse stage and the apparent absence of interkinesis (Fossey and Liebenberg, 1995). Possibly, these differences correspond to variations in the duration of the diffuse stage and in the degree of de-condensation of telophase I chromosomes among heteropteran species. Further studies are needed in order to better characterize and understand the variations observed in the meiotic cycle of different bugs.

\section{Acknowledgments}

We wish to thank Dr. Jocelia Grazia (Universidade Federal do Rio Grande do Sul) for the taxonomic identification of the species studied in this paper. We wish to thank Dr. Neide Santos (Universidade Federal de Pernambuco) for critical reading of the manuscript. We also thank Bach. Ebenézer Bernardes for collecting some of the specimens used in this study. This work was supported by grants from Conselho Nacional de Desenvolvimento Científico e Tecnológico $(\mathrm{CNPq})$ and Fundação de Amparo à Ciência e Tecnologia do Estado de Pernambuco (FACEPE).

\section{References}

Ault JG and Nicklas RB (1989) Tension, microtubule rearrangements, and the proper distribution of chromosomes in mitosis. Chromosoma 98:33-39.

Bressa MJ, Papeschi AG, Mola LM and Larramendy ML (1999) Meiotic studies in Dysdercus Guérin Méneville 1831 (Heteroptera, Pyrrhocoridae). II Neo XY in Dysdercus albofasciatus Berg 1878, a new sex chromosome determining system in Heteroptera. Chrom Res 7:503-508.

Camacho JPM, Belda J and Cabrero J (1985) Meiotic behaviour of the holocentric chromosomes of Nezara viridula (Insecta, Heteroptera) analysed by C-banding and silver impregnation. Can J Genet Cytol 27:490-497.

Fossey A and Liebenberg H (1995) Meiosis and nucleolar structures in the stick bug Carlisis wahlbergi Stal. (Coreidae, Heteroptera). Cytobios 81:7-15.
González-García JM, Antonio C, Suja JA and Rufas JS (1996) Meiosis in holocentric chromosomes: Kinect activity is ramdoly restricted to the chromatid ends of sex univalents in Graphosoma italicum (Heteroptera). Chrom Res 4:124-132.

Grozeva S and Nokkala S (1996) Chromosomes and their meiotic behavior in two families of the primitive infraorder Dipsocoromorpha (Heteroptera). Hereditas 125:31-36.

Jacobs DH and Liebenberg H (2001) Cytogenetics of Adamanotus uncotibialis Jacobs (Heteroptera, Aradidae). Caryologia 54:83-96.

Mola LM and Papeschi AG (1993) Meiotic studies in Largus rufipennis (Castelnau) (Largidae, Heteroptera): Frequency and behaviour of ring bivalents, univalents and $\mathrm{B}$ chromosomes. Heredity 71:33-40.

Nokkala S (1986) The mechanisms behind the regular segregation of the m-chromosomes in Coreus marginatus L. (Coreidae, Hemiptera). Hereditas 105:73-85.

Nokkala S and Nokkala C (1984) The occurrence of the XO sex chromosome system in Dictyonota tricornis (Schr.) (Tingidae, Hemiptera) and its significance for concepts of sex chromosome system evolution in Heteroptera. Hereditas 100:299-301.

Nokkala S and Nokkala C (1997) The absence of chiasma terminalization and inverted meiosis in males and females of Myrmus miriformis Fn. (Corizidae, Heteroptera). Heredity 78:561-566.

Nokkala S and Nokkala C (1999) Chromosomes in two bug species of Hebrus (Hebridae, Heteroptera). The occurrence of neo-XY sex chromosome system in Heteroptera. Caryologia 52:27-30.

Papeschi AG and Mola LM (1990) Meiotic studies in Acanonicus hahni (Stal) (Coreidae, Heteroptera) I. Behaviour of univalents in desynaptic individuals. Genetica 80:31-38.

Pérez R, Panzera F, Page J, Suja JA and Rufas JS (1997) Meiotic behaviour of holocentric chromosomes: Orientation and segregation of autosomes in Triatoma infestans (Heteroptera). Chrom Res 5:47-56.

Pérez R, Rufas JS, Suja JA, Page J and Panzera F (2000) Meiosis in holocentric chromosomes: Orientation and segregation of an autosome and sex chromosomes in Triatoma infestans (Heteroptera). Chrom Res 8:17-25.

Rebagliati PJ, Mola LM and Papeschi AG (2001) Karyotype and meiotic behaviour of the holokinetic chromosomes of six Argentine species of Pentatomidae (Heteroptera). Caryologia 54:339-347.

Rebagliati PJ, Papeschi AG, Mola LM, Pietrokovsky S, Gajate P, Bottazzi V and Wisnivesky-Colli C (1998) Comparative meiotic studies in Triatoma sordida (Stal) and T. guasayana Wygodzinsky \& Abalos (Reduviidae, Heteroptera). Mem Inst Oswaldo Cruz 93:309-315.

Rebollo E, Martín S, Manzanero S and Arana P (1998) Chromosomal strategies for adaptation to univalency. Chrom Res 6:515-531.

Schrader E (1960) Cytological and evolutionary implications of aberrat chromosome behaviour in the harlequin lobe of some Pentatomidae (Heteroptera). Chromosoma 11:103-128.

Schuh RT and Slater JA (1995). True Bugs of the World (Hemiptera, Heteroptera): Classification and Natural History. Cornell University Press, Ithaca, London, 336 pp. 
Satapathy SN and Patnaik SC (1988) Chromosomal studies in seven species of family Pentatomidae (Heteroptera). Caryologia 41:49-60.

Satapathy SN and Patnaik SC (1991) Chromosomal studies in five species of Indian Heteroptera (Plataspidae, Pentatomidae). Caryologia 44:55-62.

Solari AJ (1979) Autosomal synaptonemal complex and sex chromosomes without axes in Triatoma infestans (Reduviidae, Hemiptera). Chromosoma 72:225-240.
Stack SM and Anderson LK (2001) A model for chromosome structure during the mitotic and meiotic cell cycles. Chrom Res 9:175-198.

Ueshima N (1979) Animal Cytogenetics. v. 3. Insecta 6. Hemiptera II: Heteroptera. Gebrüder Borntraeger, Berlin-Stuttgart, pp 117.

Associate Editor: Yatiyo Yonenaga Yassuda 